\title{
Deficiency of the Adhesive Protein Complex Lymphocyte Function Antigen 1, Complement Receptor Type 3, Glycoprotein p150,95 in a Girl with Recurrent Bacterial Infections
}

\author{
Effects on Phagocytic Cells and Lymphocyte Functions
}

\begin{abstract}
Alain Fischer, Reinhard Seger, Anne Durandy, Barbara Grospierre, Jean Louis Virelizier, Françoise Le Deist, Claude Griscelli, Elisabeth Fischer, Michel Kazatchkine, Marie-Christine Bohler, Béatrice Descamps-Latscha, Pham Huu Trung, Timothy A. Springer, Daniel Olive, and Claude Mawas

Department of Pediatrics, Hôpital Necker, Institute National de la Santé Expérimentale et des Recherches Médicales (INSERM) U 132, Paris; INSERM U 28, Paris; Department of Pediatrics, University of Zurich, Zurich, Switzerland; INSERM U 25, Paris; Laboratoire d'Hématologie Bichat, Paris; Dana-Farber Cancer Institute, Harvard Medical School, Boston, Massachusetts; INSERM U 136, MarseilleLuminy, France
\end{abstract}

\begin{abstract}
A patient presenting delayed umbilical cord detachment, severe recurrent bacterial infections, and inability to form pus exhibited a profound defect in the expression of $\alpha$ - and $\beta$-chains of the receptor for the $\mathrm{C} 3 \mathrm{bi}$ fragment of $\mathrm{C} 3$ (CR3), lymphocyte function antigen 1 (LFA-1) molecule, and the p150,95 molecule found on neutrophils, monocytes, and lymphocyte membranes. This was shown by immunofluorescence studies using specific monoclonal antibodies, rosette formation with C3bi-coated erythrocytes, and immunoprecipitation for the LFA-1 complex. These membrane defects were responsible for abnormal phagocytic cell functions including adherence to nylon wool, cell movement, phagocytosis, and opsonized particle-induced oxidative response and for defective natural killer cell activity. In addition, lymphocyte function deficiencies previously unobserved in this disease were found. Cytolytic T lymphocyte activity was profoundly reduced; $\alpha$ - and $\gamma$-interferon production were impaired. Finally, there was no antibody production to vaccinal antigens whereas the antibody responses to polysaccharides and to cytomegalovirus were found to be normal. The cytotoxic $\mathbf{T}$ cell deficiency could be expected from previous blocking experiments of this function with monoclonal antibodies to LFA-1 and is probably related to an extremely severe deficiency in LFA-1 expression in this patient. Anomalies in interferon and in antibody production suggest additional role(s) of the LFA-1 complex in monocyte/T lymphocyte/B lymphocyte cell interactions that have not yet been envisaged.
\end{abstract}

\section{Introduction}

Two types of molecules involved in adhesive interactions of bone marrow-derived cells, lymphocyte function antigen 1 (LFA-1)

Address reprint requests to Dr. Fischer, INSERM U132, Hôpital NeckerEnfants Malades, 149 rue de Sèvres, 75015 Paris, France. 1985.

Received for publication 10 April 1985 and in revised form 29 July

1. Abbreviations used in this paper: $\mathrm{CL}$, chemiluminescence; $\mathrm{CR} 1, \mathrm{CR} 2$, and CR3, complement receptor types 1,2, and 3; CTL, cytotoxic T lymphocyte; EC3bi, erythrocytes bearing C3bi; EC3dg, erythrocytes bearing C3dg; FMLP, formyl-methionyl-leucyl-phenylalanine; GAMIG,

J. Clin. Invest.

(C) The American Society for Clinical Investigation, Inc.

$0021-9738 / 85 / 12 / 2385 / 08 \quad \$ 1.00$

Volume 76, December 1985, 2385-2392 and Mac-1, have been described using specific monoclonal antibodies $(1,2)$. LFA-1 was originally defined as a functionally important antigen present on cytotoxic $T$ lymphocytes (CTL) membranes, but this receptor is also expressed on resting $\mathrm{T}$ lymphocytes, B lymphocytes, polymorphonuclear cells (PMN), and monocytes (MN). Antibodies to LFA-1 block CTL and natural killer (NK) activities by inhibiting adhesion of killer cells to target cells. The mixed leukocyte reaction and both adhesion and phagocytosis of PMN and MN are also blocked by antibodies to LFA-1 (3). Human Mac-1, which is identical to the OKM1defined antigen, is expressed on MN, PMN, NK cells, and some lymphocytes and has been shown to be associated with the $\mathrm{C} 3 \mathrm{bi}$ receptor (4). C3bi receptor (CR3) promotes phagocytosis $(5,6)$ but does not trigger $\mathrm{H} 202$ release by phagocytic cells (7). Mac1 is structurally related to LFA-1, because both glycoproteins share a common $\beta$-subunit of $95,000 \mathrm{~mol}$ wt but have distinct $\alpha$-subunits of 155,000 and $177,000 \mathrm{~mol} \mathrm{wt}$, respectively (4). Recently, several cases of patients suffering from repeated episodes of bacterial infection with a defective expression of LFA-1 and CR3 have been reported (8-14). Profound abnormalities of phagocytic cells and of NK activity related to the lack of both receptors have been observed in these patients and prevent their normal handling of bacterial infections (8-14). Moreover, these patients lack a third membrane glycoprotein, p150,95, that shares an identical $\beta$-chain, without known functions (13). We report the structural and functional studies of PMN, MN, and T and B lymphocytes performed in a patient with delayed separation of umbilical cord and widespread life-threatening, bacterial infections. They demonstrate a severe defect in expression of both LFA- 1 and CR $3 \alpha$ - and $\beta$-chains on the membranes of lymphocytes and/or phagocytic cells. This was associated with phagocytic cell dysfunctions and abnormal NK activity but also with yet undescribed defects in cytotoxic T cell activity, $\alpha$ - and $\gamma$-interferon production, and antibody production to some antigens suggesting additional role(s) for the LFA-1 molecule.

Our patient, a female Caucasian, was born in October 1982 from fourth-degree related healthy parents after an uneventful pregnancy. She was the third child of a family whose history was negative for recurrent bacterial infection. There was no

goat anti-mouse IgG; LFA-1, lymphocyte function antigen 1; Mab, monoclonal antibody; MLR, mixed leukocyte reaction; MN, monocyte; NBT, nitroblue tetrazolium; NDV, Newcastle disease virus; NK, natural killer; OPZ, opsonized particle zymosan; PBMC, peripheral blood mononuclear cells; PHA, phytohemagglutinin; PMA, phorbol myristate acetate; ZAS, zymosan-activated serum. 
spontaneous detachment of the umbilical cord after $4 \mathrm{wk}$. Soon after surgical section of the cord, she developed omphalitis. A periumbilical cyst occurred at 5 mo of age and was excised 1 mo later. The abdominal lesion took 3 mo to heal and was complicated by both Pseudomonas aeruginosa cellulitis without pus formation and by septicemia. The patient also suffered from an external necrotizing otitis from which Pseudomonas grew. A cutaneous candidiasis of the scalp and the back developed at the age of 13 mo and was treated by local and systemic antifungal therapy. The patient was referred to Hôpital des Enfants Malades (Paris) at the age of $13 \mathrm{mo}$. She presented with enlarged liver and spleen, and severe malnutrition. Parenteral nutrition allowed the intake of $140 \mathrm{kcal} / \mathrm{kg} \cdot \mathrm{d}$ after several weeks leading to a progressive weight gain (3.8-8 $\mathrm{kg}$ within $5 \mathrm{mo}$ ). Infection phases were accompanied by an extreme hyperleukocytosis (up to $100,000 \mu \mathrm{l} / \mathrm{mm}^{3}$ ) consisting mainly of neutrophils.

\section{Methods}

Cell separation. Suspensions of PMN and peripheral blood mononuclear cells (PBMC) containing MN and peripheral blood lymphocytes (PBL) were prepared from heparinized peripheral blood by gravity sedimentation with Dextran and/or Ficol-Hypaque centrifugation. PMN preparations contained $>95 \%$ neutrophils. PBMC preparations contained 70-90\% lymphocytes, 10-25\% MN, and $<10 \%$ PMN. Phytohemagglutinin (PHA)-induced patient and control $\mathrm{T}$ cell lines were grown by the biweekly addition of interleukin 2-enriched medium prepared as previously described (15).

Monoclonal antibodies. OKM1 monoclonal antibody (Mab) that recognizes a structure closely associated with the CR3 $\alpha$-chain (16) was purchased from Ortho Pharmaceutical, Raritan, NJ. TS1/22 Mab recognized the $\alpha$-chain from LFA-1 molecule (4) and TS1/18 Mab recognized the $\beta$-chain shared by LFA-1 and CR3 (4). A second Mab (25.3), which was also shown to bind the $\alpha$-chain of LFA- 1 was used (Olive et al., manuscript submitted for publication). J3D3 is a monoclonal antibody to the human $\mathrm{C} 3 \mathrm{~b}$ receptor (CR1) (Cooklet et al., manuscript submitted for publication, 17). The Mab to the Fc $\gamma$-receptor (NEI 033) was purchased from New England Nuclear, Boston, MA. Mabs to T cells (OKT3, 4 , and 8 ) as well as to HLA class II antigens (OKIa) were purchased from Ortho Pharmaceutical (18).

Immunofluorescence studies. Indirect immunofluorescence of intact cells was done using the Mabs and fluorescein-conjugated goat-antimouse IgG (GAMIG) (Nordic-Lab, Tilburg, The Netherlands) and read through an epillumination microscope. GAMIG alone was shown not to label cells nonspecifically. Immunofluorescence was also evaluated with an Ortho cytofluorograph. Fluorescence intensity is expressed in arbitrary units.

Rosette assays. Proteins of the alternative pathway of complement C3, B, D, P, H, I, and the C3b receptor, CR 1, were purified from plasma and erythrocyte membranes as described (17-19). Sheep erythrocytes bearing $\mathrm{C} 3 \mathrm{~b}$ were prepared by interacting erythrocytes with $\mathrm{C} 3, \mathrm{~B}$, and $\mathrm{D}$ as previously described (19). Erythrocytes bearing C3bi (EC3bi) were obtained by incubating EC3b $(1 \times 108)$ with $50 \mu \mathrm{g}$ of $\mathrm{H}$ and $4 \mu \mathrm{g}$ of $\mathrm{I}$ in $1.0 \mathrm{ml}$ of medium (dextrose-gelatin-veronal buffer with magnesium and calcium salts) for $1 \mathrm{~h}$ at $37^{\circ} \mathrm{C}(19)$. C3dg-bearing erythrocytes (EC3dg) were obtained by treating EC $3 \mathrm{~b}(1 \times 108)$ with purified CR 1 and $I$ in $1.0 \mathrm{ml}$ of the above medium for $30 \mathrm{~min}$ at $37^{\circ} \mathrm{C}(20)$. For rosette assays, PMN or PBMC were incubated for $30 \mathrm{~min}$ at $30^{\circ} \mathrm{C},(106 \mathrm{cells} / 100 \mu \mathrm{l})$ with an equal volume of complement-bearing $\mathrm{E}\left(10^{7}\right.$ cells $\left./ 100 \mu \mathrm{l}\right)$. Cells were suspended in PBS-BSA containing $0.2 \%$ BSA and $0.2 \%$ soybean trypsin inhibitor, in phosphate-buffered saline-bovine serum albumin (PBS-BSA)-Ca-Mg (PBS-BSA containing $1.2 \mathrm{mM} \mathrm{Ca}^{++}$and $1.8 \mathrm{mM}$ $\mathrm{Mg}^{++}$) or in PBS-BSA-EDTA (PBS-BSA containing 0.04 M EDTA). The percentage of cells to which three or more erythrocytes were attached was assessed microscopically.
Granulocyte function. Adherence was tested by the use of a modification of the method of MacGregor et al. (21). $1 \mathrm{ml}$ of heparinized blood was filtered through a Pasteur pipette nylon wool column by gravity at room temperature. The percentage of granulocyte adherence was calculated as follows: (PMN in original sample - PMN in effluent sample/ $P M N$ in original sample) $\times 100$.

Chemotaxis. Chemotaxis was studied by a modified under-agarose technique (22). Chemoattractants used were formyl-methionyl-leucylphenylalanine (FMLP) at $10^{-7} \mathrm{M}$ or zymosan-activated normal serum (ZAS). Incubations were performed in $5 \% \mathrm{CO}_{2}$ atmosphere at $37^{\circ} \mathrm{C}$ and were terminated after $90 \mathrm{~min}$ (FMLP) and $180 \mathrm{~min}$ (ZAS), respectively.

Phagocytosis. Phagocytic assay mixtures contained $10^{6} \mathrm{PMN}, 10^{8}$ opsonized ${ }^{14} \mathrm{C}$ labeled $\mathrm{Klebsiella}$, and $10 \%$ antibody pooled serum. Incubations were carried out at $37^{\circ} \mathrm{C}$ and were terminated after $10 \mathrm{~min}$.

Nitroblue tetrazolium (NBT) test. Cytochemical screening of NBT reduction by $\mathrm{PMN}$ in suspension was performed as previously described (23) using phorbol myristate acetate (PMA, $1 \mu \mathrm{g} / \mathrm{ml}$ ) or opsonized zymosan $(\mathrm{OPZ}, 1 \mathrm{mg} / \mathrm{ml})$ as stimulants.

Oxygen consumption. $\mathrm{O}_{2}$ consumption by resting $\mathrm{PMN}$ and by $\mathrm{PMN}$ stimulated with OPZ $(1 \mathrm{mg} / \mathrm{ml})$ or PMA $(1 \mu \mathrm{g} / \mathrm{ml})$ was measured continuously with a Clark electrode Yellow Springs Instrument Co., (Yellow Springs, $\mathrm{OH}$ ) and recorded with a Gilson oxygraph (Gilson Medical Electronics, Inc., Middleton, WI) (24).

Chemiluminescence $(C L)$ production. $\mathrm{CL}$ production from $\mathrm{PMN}$ was measured using a previously described luminol-dependent photometric assay (25) in the presence of medium alone or after stimulation with latex particles $(2.5 \times 108 / \mathrm{ml}), \mathrm{OPZ}(2 \mathrm{mg} / \mathrm{ml})$, and PMA $(1 \mu \mathrm{g} / \mathrm{ml})$.

Lymphocyte function. Lymphocyte proliferation to PHA as well as to antigen (Candida antigen, tetanus toxoid, influenza virus), and mixed leukocyte reactions (MLR) were performed as previously described (26). $\alpha$ - and $\gamma$-Interferon production by mononuclear cells was measured after stimulation with Raji or TPH-1 cells, Newcastle disease virus (NDV), staphylococcal enterotoxin A, and PHA according to Virelizier and Griscelli (27). Interferon titer was measured on human amniotic cells (WISH) infected with vesicular stomatitis virus. Cytotoxic T cell function was evaluated by lysis of ${ }^{51} \mathrm{Cr}$-labeled target allogeneic PHA blasts (28). NK activity of mononuclear cells to target cell K562 was assayed as previously reported (29). Cytotoxic index in both assays was calculated according to the formula: $\left({ }^{51} \mathrm{Cr}\right.$ release in test supernatant [cpm] $-{ }^{51} \mathrm{Cr}$ spontaneous release [cpm] $/{ }^{51} \mathrm{Cr}$ total release [cpm] - ${ }^{51} \mathrm{Cr}$ spontaneous release $[\mathrm{cpm}]) \times 100$. Serum immunoglobulin levels were measured by nephelometry (IgG, A, M) or by a enzyme-linked immunoassay (IgE). Antibodies to diphtheria and tetanus toxoids were quantitated by seroneutralization, to polio virus and Bordetella pertussis, by complement fixation, and to cytomegalovirus, influenza virus, and mannan, a polysaccharide extracted from the cell wall of Candida albicans, by an enzymelinked immunoassay.

Immunoprecipitation of surface-labeled cells. Day 4 PHA-induced blasts were ${ }^{125} \mathrm{I}$-surface labeled. Cells were lysed in $0.5 \%$ NP40 in Tris$\mathrm{HCl}$ buffer $+2 \mathrm{mM}$ phenylmethylsulfonyl fluoride, then centrifuged at $100,000 \mathrm{~g}$. Lysates were precleared by addition of normal mouse serum and Staph A, or Sepharose-coupled rabbit anti-mouse Ig antibodies. The supernatants were incubated with $2 \mu \mathrm{l}$ of normal mouse serum, $100 \mu \mathrm{l}$ of Mab 25.3, or with $10 \mu \mathrm{l}$ of Mab TS1/18 prior to addition of Sepharosecoupled rabbit anti-mouse Ig antibodies. Insoluble immune complexes were eluted and analyzed by one-dimensional polyacrylamide gel electrophoresis (30). The gels were stained with Coomassie blue and scanned at $622 \mathrm{~nm}$ with an ultroscan using recording integration (LKB Produkter, Bromma, Sweden).

Expression of the results. In all assays, control cells have been run in parallel to patient cells. Age-matched controls have been used for immunofluorescence and rosette studies, granulocyte CTL and NK functions, and antibody responses.

\section{Results}

Analysis of cell surface antigens by immunofluorescence. As shown in Table I, the C3bi receptor-associated structure, the 
Table I. Cell Surface Antigen Expression Analyzed by Indirect Immunofluorescence on Neutrophils, Monocytes, and PHA-induced Lymphocyte Blasts

\begin{tabular}{|c|c|c|c|c|c|}
\hline & $\begin{array}{l}\text { OKM1 } \\
\text { (CR3 associated) }\end{array}$ & 25.3 (LFA-1 $\alpha$-chain) & TS1-18 ( $\beta$-chain) & J3D3 (CR1) & $\begin{array}{l}\text { NEI } 033 \\
\text { (Fc } \gamma \text {-receptors) }\end{array}$ \\
\hline & $\%$ & $\%$ & $\%$ & $\%$ & $\%$ \\
\hline \multicolumn{6}{|l|}{ Neutrophils } \\
\hline Patient & 0 & 0 & 0 & 41 & 35 \\
\hline Mother & 22 & 14 & 54 & 21 & 95 \\
\hline Father & 12 & 48 & 75 & 37 & 88 \\
\hline Normal values & $92 \pm 4.6$ & $60 \pm 6.3$ & $93 \pm 0.6$ & $62 \pm 28$ & $93 \pm 5.2$ \\
\hline \multicolumn{6}{|l|}{ Monocytes } \\
\hline Patient & 0 & 0 & 0 & 30 & \\
\hline Mother & 55 & 16 & 78 & 29 & \\
\hline Father & 60 & 58 & 60 & 20 & \\
\hline Normal values \pm SEM & $60 \pm 5.6$ & $52 \pm 9.6$ & $43 \pm 2.1$ & $17 \pm 3.0$ & \\
\hline \multicolumn{6}{|c|}{ PHA-induced lymphoblasts } \\
\hline Patient & $<1$ & 0 & 0 & ND & \\
\hline Mother & $<1$ & 88 & ND & ND & \\
\hline Father & $<1$ & 83 & 72 & ND & \\
\hline Normal values & $<1$ & $86 \pm 5.0$ & $89 \pm 6.5$ & ND & \\
\hline
\end{tabular}

Values indicate the percentage of positive cells with each monoclonal reagent \pm standard error of the mean. ND, not done.

LFA- $1 \alpha$-chain, and the common $\beta$-chain were not detected as revealed by visual indirect immunofluorescence with OKM1, 25.3 (or TS1/22, data not shown), and TS1/18 specific Mabs, respectively, on the patient's PMN and MN. Similarly, LFA-1 $\alpha$ - and $\beta$-chains were neither detected on PHA-induced T blasts (Table I) nor on PBL (data not shown). These results were confirmed by cytofluorography on a PHA-induced T cell line. 30- d-old T cells had very little expression, if any, of LFA- $1 \alpha$-subunit as detected by Mab 25.3 (Fig. 1). Incubation of monocytes or PHA-induced blasts for $24 \mathrm{~h}$ to $4 \mathrm{~d}$ with either $700 \mathrm{U}$ of $\gamma$ interferon or PMA $(2-200 \mathrm{ng} / \mathrm{ml})$ triggered neither the expression of C3bi $\alpha$-chain nor of LFA-1 $\alpha$ - and $\beta$-chains on the two cell populations (data not shown). In contrast, C3b receptor (CR1) and Fc $\gamma$-receptor were detected although Fc $\gamma$-receptor expres-
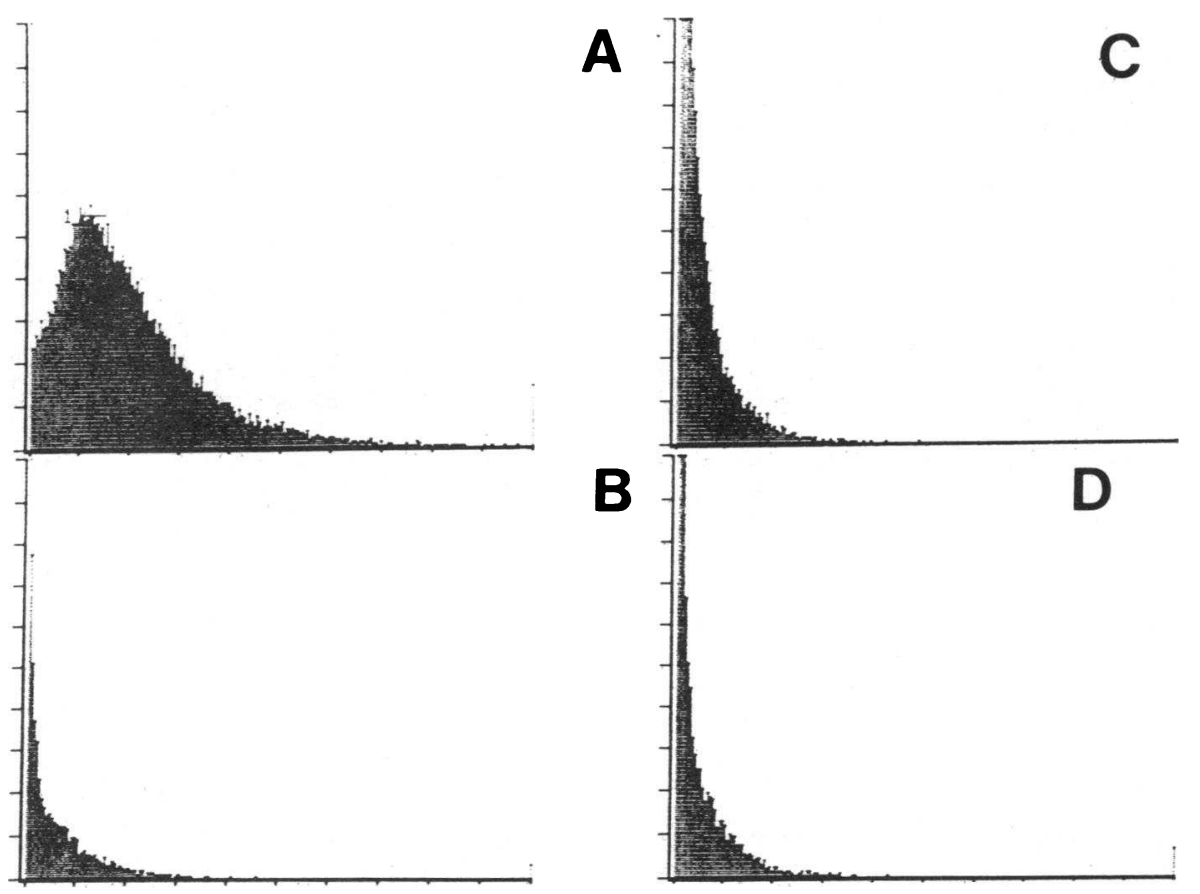

Figure 1. Immunofluorescent flow cytometry of PHA-activated interleukin 2-grown T cells. $T$ cells were indirectly stained with 25.3 Mab (anti LFA-1) and fluorescence-labeled goat anti-mouse immunoglobulin (GAMIG) or with GAMIG alone (lower part). (A) Control, 25.3 + GAMIG staining; $(B)$ control, GAMIG staining; $(C)$ patient, 25.3 + GAMIG staining; $(D)$ patient, GAMIG staining. The intensity of fluorescence (abscissa) is expressed in arbitrary units (linear scale). 
sion was slightly lower than on control cells. This observation may be secondary to the presence of IgG on the Fc $\gamma$-receptors in the patient because of infection in that PMN were found to be fluorescent by use of an anti-human IgG antiserum. No difference in OKM 1 and LFA-1 expression was observed before and after parenteral renutrition. Positive OKM1 and LFA-1 expression on PMN, MN, and PHA-induced blasts was observed in the patient's parents although the percentage of positive PMN was lower than in controls. Differences in LFA $\alpha$-chain expression between the parents could be explained by an expected variation in heterozygous subjects. Other membrane markers including T3, T4, and T8 antigen on T cells, surface immunoglobulins on B cells, HLA class I and II molecules as well as $\beta_{2-}$ microglobulin were found to be normally expressed on the patient's cells (data not shown).

$E C 3 b, E C 3 b i$, and EC $3 d g$ rosette formation. As shown in Table II, percentages of PMN and PBMC forming rosettes with EC3b were approximately the same in the patient and in the control. In contrast, no PMN and only $11 \%$ of PBMC from the patient formed C3bi rosettes in PBS-BSA-Ca-Mg compared with $61 \%$ PMN and 42\% PBMC in the control. No PMN, 5\% patient PBMC, and 16\% control PBMC bound EC3bi in PBS-BSAEDTA. No PMN from the patient bound EC3dg in the presence or in the absence of divalent cations. $\sim 10 \%$ patient PBMC bound EC3dg both in PBS-BSA-Ca-Mg and in PBS-BSA-EDTA, whereas 36\% control PBMC bound EC3dg in PBS-BSA-Ca-Mg and $10 \%$ bound EC3dg in the presence of EDTA.

Immunoprecipitation studies. As shown in Fig. 2, the LFA- $1 \alpha$-chain of $\sim 180,000$ mol wt and the $\beta$-chain of 94,000 mol wt recognized by the Mab 25.3 and TS1/18, respectively, as well as a 155,000-mol wt band coprecipitated by TS1/18 in control blasts, were not detected on patient PHA blasts although they were present in paternal and control blasts. Gel scanning did not allow a quantitation of residual amounts of $\alpha$ - and $\beta$ chains that could be precipitated on the membrane of patient PHA blasts because peak intensity was below the threshold of detection ( $<0.2 \%$ of the contaminating actin peak).

PMN functions. Table III indicates the abnormalities found in PMN functions. The observed defects were present before and after parenteral renutrition. The patient's PMN did not adhere to nylon wool. The random migration of PMN was impaired as was the chemotactic response to ZAS or to FMLP. Phagocytosis of opsonized Klebsiella particles by the patient's cells

Table II. Percentage of Rosette-forming PMN and $P B M C$ with EC $3 b, E C 3 b i$, and EC $3 d g \pm 1$ SEM

\begin{tabular}{|c|c|c|c|c|}
\hline & \multicolumn{2}{|c|}{ Patient } & \multicolumn{2}{|c|}{ Control } \\
\hline & PMN & PBMC & PMN & PBMC \\
\hline EC3b & $55 \pm 5$ & $46 \pm 6$ & $74 \pm 3$ & $54 \pm 4$ \\
\hline \multicolumn{5}{|l|}{ EC3bi } \\
\hline PBS-BSA-Ca-Mg & 0 & $11 \pm 1$ & $61 \pm 5$ & $42 \pm 3$ \\
\hline PBS-BSA-EDTA & 0 & $5 \pm 4$ & 0 & $16 \pm 8$ \\
\hline \multicolumn{5}{|l|}{ EC3dg } \\
\hline PBS-BSA-Ca-Mg & 0 & $13 \pm 4$ & $23 \pm 5$ & $36 \pm 4$ \\
\hline PBS-BSA-EDTA & 0 & $10 \pm 1$ & 0 & $10 \pm 3$ \\
\hline
\end{tabular}

Binding of EC3bi to PBMC in the absence of cations is probably due to lowaffinity interaction with CRI (30).

Cation-dependent binding of EC3dg to control but not patient PMN in the presence of cations is likely to be due to an interaction with CR3.

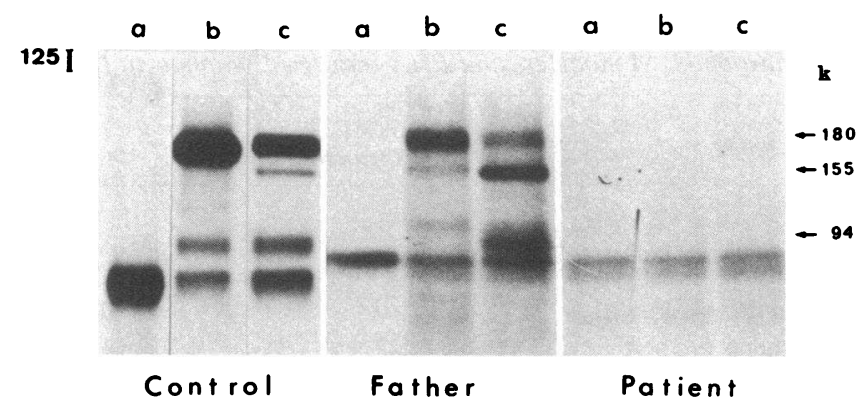

Figure 2. One-dimensional gel electrophoresis of immune precipitates from control, patient's father, and patient surface-iodinated PHA-blast lysates obtained with $(a)$ normal mouse serum, control precipitate, $(b)$ Mab 25.3, anti- $\alpha$ LFA-1 chain, (c) Mab TS1/18 anti- $\beta$ chain. Control precipitates were run on a separate gel. A band of $80,000 \mathrm{~mol}$ wt present in all precipitates is $\alpha$-chain of iodinated Ig from contaminating B cells. $\mathbf{k}$, thousands in molecular weight.

was reduced to $15 \%$ of normal. PMN failed to reduce NBT and to consume $\mathrm{O}_{2}$ when stimulated with $\mathrm{OPZ}$. In contrast, stimulation of oxidative PMN metabolism was near normal when a soluble activating agent such as PMA was used. A similar dissociation was noted in CL generation by PMN, wherein the response to $\mathrm{OPZ}$ was markedly depressed, whereas spontaneous CL emission and $C L$ responses to soluble stimulants such as PMA and nonopsonized particles as latex were nearly normal or even enhanced.

Lymphocyte functions. Mitogen and antigen-induced lymphocyte proliferations as well as mixed leukocyte reactions were normal in the patient (Table IV). Growth of T cell lines could be achieved in the presence of interleukin 2. Cytotoxic $T$ cell activity was found to be profoundly impaired (Fig. 3). Spontaneous NK activity was found to be diminished on four occasions,

\section{Table III. PMN Cell Functions}

\begin{tabular}{|c|c|c|}
\hline Function tested & Patient & Control \\
\hline Adherence to nylon (\%) & 0 & $>50$ \\
\hline \multicolumn{3}{|l|}{ Migration } \\
\hline Random ( $\mathrm{mm}$ ) & 0.06 & $0.7 \pm 0.14$ \\
\hline $\mathrm{ZAS}(\mathrm{mm})$ & 0.82 & $2.20 \pm 0.11$ \\
\hline FMLP $(\mathrm{mm})$ & 0.30 & $2.13 \pm 0.34$ \\
\hline \multicolumn{3}{|l|}{ Phagocytosis of Klebsiella } \\
\hline$\left(\mathrm{cpm} \times 10^{-3}\right)$ & 1.1 & $7.5 \pm 2.5$ \\
\hline \multicolumn{3}{|l|}{ NBT } \\
\hline OPZ (\% positive cells) & $\mathbf{0}$ & $>90$ \\
\hline PMA (\% positive cells) & 100 & $>90$ \\
\hline \multicolumn{3}{|l|}{$\mathrm{O}_{2}$ consumption } \\
\hline \multicolumn{3}{|l|}{ Spontaneous } \\
\hline (nanoatoms $/ \mathrm{min} \cdot 10^{6} \mathrm{cells}$ ) & 1.5 & $1.6 \pm 0.7$ \\
\hline $\mathrm{OPZ}$ (nanoatoms $/ \mathrm{min} \cdot 10^{6}$ cells) & 2.1 & $16.0 \pm 2.5$ \\
\hline PMA (nanoatoms $/ \mathrm{min} \cdot 10^{6}$ cells) & 5.7 & $11.9 \pm 3.2$ \\
\hline \multicolumn{3}{|l|}{ CL } \\
\hline Spontaneous $\left(M L I^{*} / 10^{6}\right.$ cells $)$ & 40,535 & $26,750 \pm 3,000$ \\
\hline OPZ $\left(M L I^{*} / 10^{6}\right.$ cells $)$ & 68,210 & $413,360 \pm 32,000$ \\
\hline PMA $\left(M L I^{*} / 10^{6}\right.$ cells $)$ & 191,340 & $167,630 \pm 13,000$ \\
\hline Latex $\left(M L I * / 10^{6}\right.$ cells $)$ & 156,680 & $145,880 \pm 8,230$ \\
\hline
\end{tabular}

Control data are given \pm standard error of the mean.

* MLI, maximum light intensity. 
Table IV. Lymphocyte Proliferation

\begin{tabular}{lcc}
\hline Stimulation & Patient PBL & Control PBL \\
\hline & $c p m \times 10^{-3} \pm$ SEM & $c p m \times 10^{-3} \pm$ SEM \\
Nil & $0.7 \pm 0.1$ & $0.5 \pm 0.1$ \\
PHA & & \\
$1: 10,000$ & $34 \pm 3$ & $22.5 \pm 2$ \\
$\quad 1: 700$ & $229 \pm 12$ & $81.5 \pm 5$ \\
Nil & $1.0 \pm 0.3$ & $0.8 \pm 0.1$ \\
Allogeneic cells & $29 \pm 3$ & $38 \pm 4$ \\
Nil & $0.6 \pm 0.2$ & $0.9 \pm 0.2$ \\
Tetanus toxoid & $13 \pm 2$ & $8 \pm 0.5$ \\
Candida albicans & $23 \pm 1$ & $34 \pm 3$ \\
Influenza virus A/X31 & $11 \pm 1$ & $19 \pm 0.5$ \\
\end{tabular}

PHA-induced proliferation was measured by $\left[{ }^{3} \mathrm{H}\right]$ thymidine uptake at day 3, allogeneic cell-induced proliferation and antigen-induced proliferations by $\left[{ }^{3} \mathrm{H}\right]$ thymidine uptake at day 6 . Cultures were performed in triplicate.

but the in vitro response of NK cells to incubation with interferon was variable, i.e., abolished in some experiments but significantly detectable in others as seen in all four experiments shown in Table V. These variations could not be correlated with therapy, infection, or nutrition status or any putative alteration in LFA- 1 membrane expression. $\alpha$ - and $\boldsymbol{\gamma}$-Interferon production was found to be profoundly impaired as shown in Table VI. Interferon secretion, although very low, was not however entirely abolished even when using potent inducers such as staphylococcal enterotoxin A or Raji cells, and was normal after incubation with NDV. As shown in Table VII, the humoral immune response was found partially impaired in the patient. Although serum immunoglobulin levels were increased, the in vivo antibody response to several antigens was absent when tested after four vaccinations and after the patient had been realimented. However, isohemagglutinins and antibodies to mannan, a polysaccharide extracted from Candida albicans, a yeast that provoked a persisting infection in the patient, were normally found as were antibodies to cytomegalovirus which was detected in the urine.

\section{Discussion}

Recurrent bacterial infections have been associated with the deficiency in LFA-1 and CR3 membrane glycoproteins in neutrophils and MN (8-14). Similar clinical features have been observed in our patient, including delayed umbilical cord detachment with omphalitis, severe and recurrent bacterial infections from infancy, and marked leukocytosis. In all described patients (814) PMN and MN adhesion to either plastic glass or endothelial

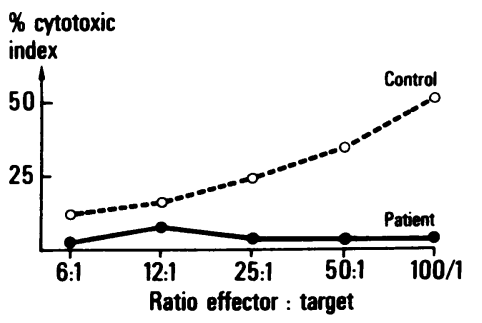

Figure 3. Cytotoxic $\mathrm{T}$ cell activity to allogeneic PHAinduced blasts. Cytotoxic index was measured as for NK cytotoxic index (Table V).
Table V. NK Activity

\begin{tabular}{|c|c|c|c|c|c|}
\hline \multirow[b]{2}{*}{ Experiment } & \multirow{2}{*}{$\begin{array}{l}\text { Interferon* } \\
\text { added }\end{array}$} & \multicolumn{4}{|c|}{ Effector/target ratioł } \\
\hline & & $6: 1$ & $12: 1$ & $25: 1$ & $50: 1$ \\
\hline & $\%$ & $\%$ & $\%$ & $\%$ & $\%$ \\
\hline \multirow[t]{2}{*}{1} & 0 & 2 & 2 & 5 & 6 \\
\hline & + & 2 & 5 & 8 & 9 \\
\hline \multirow[t]{2}{*}{2} & 0 & $<1$ & 3 & 3 & 10 \\
\hline & + & 8 & 12 & 25 & 39 \\
\hline \multirow[t]{2}{*}{3} & 0 & $<1$ & 2 & 2 & 9 \\
\hline & + & 8 & 10 & 21 & 35 \\
\hline \multirow[t]{2}{*}{4} & 0 & $<1$ & $<1$ & $<1$ & $<1$ \\
\hline & + & 5 & 4 & 5 & 9 \\
\hline \multicolumn{6}{|c|}{ Normal values } \\
\hline$(n=30)$ & 0 & $17 \pm 13$ & $27 \pm 16$ & $41 \pm 19$ & $53 \pm 21 \S$ \\
\hline \pm SEM & + & $35 \pm 14$ & $54 \pm 18$ & $69 \pm 18$ & $76 \pm 15$ \\
\hline
\end{tabular}

* $700 \mathrm{U}$ of $\gamma$-interferon was added in the experiment.

$¥ \mathrm{~K} 562$ cells were used as target cells.

$\S \%$ cytotoxic index was determined according to the formula $\left({ }^{51} \mathrm{Cr}\right.$ release in test supernatant $(\mathrm{cpm})-{ }^{51} \mathrm{Cr}$ spontaneous release $(\mathrm{cpm}) /{ }^{51} \mathrm{Cr}$ total release $(\mathrm{cpm})$

$-{ }^{31} \mathrm{Cr}$ spontaneous release $(\mathrm{cpm}) \times 100$.

cells, cell migration, phagocytosis, and opsonized particle-driven oxidative metabolism were found to be impaired. In addition NK deficiency has been observed in some patients $(8,9,11)$. In one patient observed, the defect was shown to be reversible by bone marrow transplantation indicating its marrow origin (31). Most of PMN, MN, and NK lineage abnormalities can easily be explained by the common denominator of a defective membrane expression of both LFA-1 and CR3 molecules on the patients' cells (1-5). These molecules were studied by immunofluorescence and immunoprecipitation for LFA-1 and by immunofluorescence and rosetting for CR3. The expression of the $\beta$-chain common to both LFA- 1 and CR3 was also shown to be defective on our patient's cells. The absence of CR3 function on this patient's cells as revealed by the lack of binding of EC3bi to PMN and the low percentage of patient PBMC that formed cation-dependent EC3bi rosettes (6\%) as compared with controls, was in contrast with the unimpaired capacity of patient leukocytes to form EC3b rosettes and of patient PBMC to express CR2 (EC3dg binding in the absence of divalent cations) (32). In addition, there was no lack of other known membrane glyco-

Table VI. $\alpha$ - and $\gamma$-Interferon Production by PBL or PBMC

\begin{tabular}{lccccccc}
\hline & \multicolumn{6}{l}{ Interferon units in supernatants of PBL stimulated with } \\
\cline { 2 - 7 } $\begin{array}{l}\text { Subject } \\
\text { tested }\end{array}$ & PHA & SEA & RAJI cells & THP-1 cells & Polylc & NDV \\
\hline & $U$ & $U$ & $U$ & $U$ & $U$ & $U$ \\
Patient & 3 & 36 & 18 & 3 & 4.5 & 1,536 \\
Control & 96 & 576 & 2304 & 192 & 72 & 4,608 \\
& & & & & & & \\
\hline
\end{tabular}

Interferon units were measured on WISH human amniotic cells infected with vesicular stomatitis virus.

PolyIc, polyinosinic-polycytidylic acid; SEA, staphylococcal enterotoxin A; THP-1, human acute monocytic leukemia cell line. 
Table VII. Humoral Immune Response

\begin{tabular}{lcc}
\hline & Patient & Normal values \\
\hline Serum immunoglobulins & & \\
IgG $(\mathrm{g} /$ liter $)$ & 22.00 & $5.3-10.1$ \\
IgA $(\mathrm{g} /$ liter $)$ & 3.56 & $0.34-0.78$ \\
IgM $(\mathrm{g} / \mathrm{liter})$ & 6.95 & $0.54-1.06$ \\
IgE $(I U / \mathrm{ml})$ & 380 & $5-20$ \\
Serum antibodies & & \\
Isohemagglutinins & & \\
$\quad$ Anti A $\left(\right.$ titer $\left.\times 10^{-1}\right)$ & 256 & $>64$ \\
$\quad$ Anti B $\left(\right.$ titer $\left.\times 10^{-1}\right)$ & 128 & $>64$ \\
Mannan from candida & & \\
$\quad$ albicans $(U / m l)$ & 2,600 & $>1,000$ \\
Cytomegalovirus $(U / m l)$ & 0.59 & $>0.25$ \\
Tetanus toxoid $(I U / m l)$ & 0 & $>0.1$ \\
Diphtheria toxoid $(I U / m l)$ & 0 & $>0.1$ \\
Polio virus $\left(\right.$ titer $\left.\times 10^{-I}\right)$ & 0 & $>16$ \\
Bordetella pertussis & & \\
$\quad\left(\right.$ titer $\left.\times 10^{-I}\right)$ & 0 & $>40$ \\
Influenza virus $\mathrm{A} / \mathrm{X} 31$ & & $>200$ \\
$\quad($ ng/ml $)$ & 0 & \\
\hline
\end{tabular}

Serum immunoglobulins concentrations were measured by nephelometry (IgG, A, M) or by an enzyme-linked immunoassay (ELISA) (IgE). Serum antibody concentrations were determined by either seroneutralization (tetanus and diphtheria toxoids), complement fixation polio virus and Bordetella pertussis), or by ELISA (cytomegalovirus, influenza virus, mannan). These data have been observed after four stimulations with tetanus and diphtheria toxoids, polio virus, and Bordetella pertussis and two stimulations for influenza virus.

proteins in that HLA class I and II antigens, $\beta_{2}$-microglobulin, Fc $\gamma$-receptor, T cell associated glycoproteins were expressed.

The cell membrane abnormalities observed cannot be explained by either the young age or by infections, in that cells from a heavily infected age-matched patient with chronic granulomatous disease were found to express LFA-1 and CR3 normally (data not shown). The partial deficiency in OKM1 and LFA-1 chain expression by parental PMN suggests the possible detection of carriers. Parental cell marker abnormalities did not lead to any impairment of PMN functions. The defective expression of LFA-1, CR3, and a third protein p150,95 sharing the same $\beta$-chain on the surface of leukocytes in the patient described and in others is strongly suggestive of a primary defect in the $\beta$-chain. This is further confirmed by the detection of LFA-1 $\alpha$-chain in the cytoplasm of patient PHA blasts (11, Grospierre et al., manuscript submitted for publication) while $\beta$-chain can not be detected.

In addition to the aforementioned functional defects of phagocytic cells and $\mathrm{T}$ lymphocytes, we observed other abnormalities that have not yet been described in the adhesive protein deficiency. In the patient herein described, a severe CTL deficiency was found in spite of a normal allogeneic proliferative response. This defect can easily be related to LFA-1, because this molecule has been shown to play a role in the adhesion of the CTL to target cells (3).

A profound impairment of the interferon system has been observed in our patient, and is consistent with previous reports in which the membrane glycoprotein defects have not been de- scribed $(30,33)$. How the defect of interferon production relates to the abnormal expression of LFA- 1 and CR3 antigens is not understood. We have been unable to inhibit $\alpha$ - or $\gamma$-interferon production in normal leukocytes by addition of antibodies to these antigens in culture (data not shown) although an antibody to the $\beta$-chain of LFA- 1 has been shown to block the $\gamma$-interferon production by cytotoxic T cells (A. McMichael, personal communication).

Because Mab to the LFA-1 $\alpha$-chain such as TS1/22 (3) or 25.3 (Olive et al., submitted) have been shown to completely inhibit the MLR, it is puzzling that the patient's cells did respond in the MLR. The presence of LFA-1 molecules on the stimulator cells may be sufficient to permit responder/stimulator cell interaction. This could be easily tested by using cells from two different affected patients as responders and stimulators.

A third abnormality found in our patient, the absence of antibody response after vaccination, had not been clearly explained by the known functions of the adhesive protein complex. It is unlikely that this was due to malnutrition because the patient attained normal weight when she was vaccinated. It may be related to an as yet unknown role of LFA-1 in cell interaction leading to antibody response since 25.3 or TS1/22 Mab to LFA$1 \alpha$-chain blocks in vitro antibody response to influenza virus but not to mannan of control lymphocytes (Fischer et al., manuscript in preparation). This could be a consequence of defective MN-T cell interaction leading to the activation of helper T lymphocytes in that LFA-1 has been shown to be involved in MN$T$ lymphocyte interaction $(3,4,11)$. However, the antigen-induced $T$ lymphocyte proliferation was found normal in the patient. Although expressed on the membrane of B lymphocytes, LFA-1 has been considered not to play a role at the B cell level (34). The present observation suggests that LFA-1 could be involved in T lymphocyte-B lymphocyte and/or MN-B lymphocyte interaction required for some antibody responses. It is possible that antibody responses to polysaccharides such as AB blood group substances and mannan, being either independent or less $T$ cell-dependent than antibody responses to proteins, would not be impaired in the absence of LFA- 1 expression. The positive antibody response to cytomegalovirus might be due to a prolonged exposure of patient's lymphocytes to the virus as opposed to vaccinal antigens. Davignon et al. (35) have previously shown that Mab to LFA-1 block T cell-dependent, but not $T$ cell-independent, responses in activity in the mouse. These lymphoid functional abnormalities have not been reported thus far in association with LFA-1 deficiency in other patients except for a CTL defect in one (9). The severity of the deficiency of LFA-1 expression as shown by immunofluorescence analysis of PHAinduced, interleukin 2-dependent $T$ cells and immunoprecipitation of PHA blasts could account for these lymphoid cell functional defects. Normal PHA blasts are known to increase their surface expression of LFA- 1 by six- to eightfold compared with unstimulated cells (10), and LFA-1-deficient lymphocytes of a number of patients have been shown to express detectable amounts of LFA-1 (5-50\% of controls) whereas PHA blasts from our patient have a LFA-1 expression that is below or at the lowest limit of detection $(10,11,13,14)$.

Most of the complex defects observed in the patient are thus probably related to the LFA-1 and CR3-deficient expression on lymphocytes, PMN, and MN. This clearly demonstrates the crucial role of both receptors in adhesive interactions, although not all interactions are defective in that, for example, $T$ helper cell-macrophage interactions for antigen presentation remain 
undisturbed as illustrated by a positive in vivo delayed-type skin test and a positive antigen-induced lymphocyte proliferation. These cellular deficiencies serve to delineate the functional role of the closely related molecules LFA-1 and CR3. It is striking to note that all of the patients who are deficient in LFA-1 and CR3 glycoproteins presented with severe bacterial infections probably related to the profound impairment of the phagocytic cell functions (8-14). Severe viral infections occurred neither in our patient nor in the reported cases except in one who died of an infection due to a picoRNA virus (11), contrasting with the findings in our patient of an impairment of nearly all of the immune effector functions involved in viral immunity, interferon production, T cell cytotoxicity, NK activity, and antibody production. Three explanations may account for this discrepancy: (a) most of the patients are not entirely deficient in LFA-1 expression and do have at least some cytotoxic functions (10); (b) several patients died before they could have encountered viruses; and $(c)$ a persisting virus like cytomegalovirus in our patient might have elicited a normal immune response, in bypassing the function of LFA- 1 in cell interactions by activating T lymphocytes with a strong affinity to antigen which do not need LFA-1 for cell interactions (36). Altogether these data suggest that LFA-1 participates in or is closely associated with a number of different $T$ lymphocyte functional pathways. The comparison of the functional consequences of partial and total deficiencies of LFA-1 expression tells us about the relative requirement of this molecule in different types of intercellular interactions.

\section{Acknowledgments}

The technical assistance of Ms. C. Barbat, A. M. Laharie, P. Zanetti, O. Journet, and C. Harre is gratefully acknowledged. We are indebted to Dr. Campelli for kindly referring the patient, and Ms. V. Serrurier for typing the manuscript. We thank Mr. M. Levinson for reading the manuscript.

This work has been supported by grants from INSERM. Reinhard Seger is a recipient of a scholarship from the Schweizerische Stiftung für Medizinische-Biologische Stipendien.

\section{References}

1. Sanchez-Madrid, F., A. M. Krensky, C. F. Ware, E. Robbins, J. L. Strominger, S. J. Burakoff, and T. A. Springer. 1982. Three distinct antigens associated with human T lymphocyte-mediated cytolysis: LFA1, LFA-2 and LFA-3. Proc. Natl. Acad. Sci. USA. 79:7489-7493.

2. Beller, D. I., T. A. Springer, and R. D. Schreiber. 1982. Anti Mac1 selectively inhibits the mouse and human type three complement receptor. J. Exp. Med. 156:1000-1009.

3. Ware, C. F., F. Sanchez-Madrid, A. M. Krensky, S. J. Burakoff, J. L. Strominger, and T. A. Springer. 1983. Human lymphocyte function associated antigen-1 (LFA-1): identification of multiple antigenic epitopes and their relationship to CTL-mediated cytotoxicity. J. Immunol. 131: 1182-1188.

4. Sanchez-Madrid, F., J. A. Nagy, E. Robbins, P. Simon, and T. A. Springer. 1983. A human leukocyte differentiation antigen family with distinct $\alpha$-subunits and a common $\beta$-subunit. J. Exp. Med. 158:17851803.

5. Ross, G. D. 1982. Structure and function of membrane complement receptors. Fed. Proc. 211:3089-3093.

6. Wright, S. D., L. S. Craigmyle, and S. C. Silverstein. 1983. Fibronectin and serum amyloid $\mathrm{P}$ component stimulate $\mathrm{C} 3 \mathrm{~b}$ and $\mathrm{C} 3 \mathrm{bi}$ mediated phagocytosis in cultured human monocytes. J. Exp. Med. 158: 1338-1343.

7. Wright, S. D., and S. C. Silverstein. 1983. Receptors for C3b and
C3bi promote phagocytosis but not the release of toxic oxygen from human phagocytes. J. Exp. Med. 158:2016-2023.

8. Dana, N., R. F. Todd, J. Pitt, T. A. Springer, and M. A. Arnaout. 1984. Deficiency of a surface glycoprotein (Mol) in man. J. Clin. Invest. 73:53-59.

9. Beatty, P. G., H. D. Ochs, J. M. Harlan, T. H. Price, H. Rosen, R. F. Taylor, J. A. Hansen, and S. J. Klebanoff. 1984. Absence of monoclonal antibody defined protein complex in boy with abnormal leucocyte function. Lancet. i:535-537.

10. Arnaout, M. A., H. Spits, C. Terhorst, J. Pitt, and R. F. Todd III. 1984. Deficiency of a leukocyte surface glycoprotein (LFA-1) in two patients with Mo-1 deficiency. J. Clin. Invest. 74:1291-1309.

11. Springer, T. A., W. S. Thompson, L. J. Miller, F. C. Schmalstieg, and D. C. Anderson. 1984. Inherited deficiency of the Mac-1, LFA-1, p. 150,95 glycoprotein family and its molecular basis. J. Exp. Med. 160: 1901-1918.

12. Bowen, T. S., H. D. Ochs, L. C. Altman, T. H. Price, D. E. Van Epps, D. L. Brautigan, R. E. Rosin, W. D. Perkins, B. M. Babior, S. J. Klebanoff, and R. J. Wedgwood. 1982. Severe recurrent bacterial infections associated with defective adherence and chemotaxis in two patients with neutrophils deficient in a cell-associated glycoprotein. $J$. Pediatr. 101:932-940.

13. Anderson, D. C., F. C. Schmalstieg, M. A. Arnaout, S. Kohl, M. F. Tosi, N. Dana, C. J. Buffone, B. J. Hughes, B. R. Brinkcey, W. D. Dickey, J. S. Abramson, T. Springer, L. A. Boxer, J. M. Hollers, and C. W. Smith. 1984. Abnormalities of polymorphonuclear leukocyte function associated with a heritable deficiency of high molecular weight surface glycoproteins (GP 138): common relationship to diminished cell adherence. J. Clin. Invest. 74:536-551.

14. Miedema, F., P. A. T. Tetteroo, F. G. Tepstra, G. Keizer, M. Roos, R. S. Weening, C. M. R. Weemaes, D. Roos, and C. J. M. Melief. 1985. Immunologic studies with LFA-1 and Mol-deficient lymphocytes from a patient with recurrent bacterial infections. J. Immunol. 134:30753081.

15. Fischer, A., G. Sterkers, D. Charron, and A. Durandy. 1985. HLA Class II restriction governing cell cooperation between antigenspecific helper $\mathrm{T}$ lymphocytes, B lymphocytes and monocytes for in vitro antibody production to influenza virus. Eur. J. Immunol. 15:620626.

16. Wright, S. D., P. E. Rao, W. C. Van Voorhis, L. S. Craigmyle, K. Iida, M. A. Talle, E. F. Westberg, G. Golstein, and S. C. Silverstien. 1983. Identification of the $\mathrm{C} 3 \mathrm{bi}$ receptor of human monocytes and macrophages by using monoclonal antibodies. Proc. Natl. Acad. Sci. USA. 80:5699-5703.

17. Fearon, D. T. 1980. Identification of the membrane glycoprotein that is the $\mathrm{C} 3 \mathrm{~b}$ receptor of the human erythrocyte, polymorphonuclear leukocyte, B lymphocytes and monocyte. J. Exp. Med. 152:20-30.

18. Reinherz, E. L., S. Meuer, K. A. Fitzgerald, R. E. Hussey, H. Levine, and S. F. Schlossman. 1982. Antigen recognition by human $T$ lymphocytes. Cell. 30:735-743.

19. Kazatchkine, M., D. T. Fearon, and K. F. Austen. 1979. Human alternative complement pathway: membrane-associated sialic acid regulates the competition between B and beta-1-H for cell bound C3b. $J$. Immunol. 122:75-81.

20. Medof, M. E., K. Iida, C. Mold, and W. Nussenzweig. 1982. Unique role of the complement receptor CR1 in the degradation of $\mathrm{C} 3 \mathrm{~b}$ associated with immune complexes. J. Exp. Med. 156:1739-1754.

21. MacGregor, R. R., P. J. Spagnulo, and A. C. Lentnek. 1974. Inhibition of granulocyte adherence by ethanol, prednisone and aspirin measured with an assay system. N. Engl. J. Med. 291:642-646.

22. Nelson, R. D., P. G. Quie, and R. L. Simmons. 1975. Chemotaxis under agarose: a new and simple method for measuring chemotaxis and spontaneous migration of human polymorphonuclear leukocytes and monocytes. J. Immunol. 115:1650-1656.

23. Newburger, P. E., J. S. Pagano, and J. S. Greenberger. 1980. Dissociation of opsonized particle phagocytosis and respiratory burst activity and an Epstein-Barr virus infected myeloid cell line. J. Cell. Biol. $85: 549-554$ 
24. Seger, R. A., L. Tiefenauer, T. Matsunaga, A. Wildfeuer, and P. E. Newburger. 1983. Chronic granulomatous disease due to granulocytes with abnormal NADH-oxidase activity and deficient cytochrome b. Blood. 61:423-428.

25. Nguyen, A. T., R. Golub, and M. N. Feuilleet-Fieux. 1983. Modulation of granulocyte and monocyte chemiluminescence responses: evidence for distinct free radical generating systems. J. Clin. Lab. Immunol. 12:47-59.

26. Griscelli, C., A. Durandy, D. Guy-Grand, F. Daguillard, C. Herzog, and M. Prunieras. 1978. A syndrome associating partial albinism and immunodeficiency. Am. J. Med. 65:691-702.

27. Virelizier, J. L., and C. Griscelli. 1980. Interferon administration as an immunoregulatory and antimicrobial treatment in children with defective interferon secretion. In Primary Immunodeficiencies. M. Seligmann and W. Hitzig, editors. Elsevier/North Holland, Amsterdam. 473-484.

28. Mawas, C., M. Sasportes, and D. Charmot. 1975. Cell-mediated lympholysis: independence of mixed lymphocyte reactions and $\mathrm{T}$ cell responses from the in vitro generation of cytotoxic effectors in primary immunodeficiency diseases. Clin. Exp. Immunol. 20:83-88.

29. Virelizier, J. L., A. Lagrue, A. Durandy, F. Arenzana, C. Oury, and C. Griscelli. 1982. Reversal of natural killer defect in a patient with Chediak-Higashi syndrome after bone marrow transplantation. $N$. Engl. J. Med. 306:1055-1056. (Lett.)

30. Laemmli, U. K. 1970. Cleavage of structural proteins during the assembly of the head of bacteriophage T4. Nature (Lond.). 227:680-682.
31. Fischer, A., H. T. Pham, B. Descamps-Latscha, B. Grospierre, I. Gerota, N. Perez, C. Scheinmetzler, A. Durandy, J. L. Virelizier, and C. Griscelli. 1983. Bone marrow transplantation for inborn error of phagocytic cells associated with defective adherence, chemotaxis, and oxidative response during opsonized particle phagocytosis. Lancet. ii: 473-476.

32. Ross, G. D., S. L. Newman, J. D. Lambris, J. E. Devery-Pocius, J. A. Kain, and P. J. Lachmann. 1983. Generation of three different fragments of bound $\mathrm{C} 3$ with purified factor I or serum. Location of binding sites in the $\mathrm{C} 3$ fragments for factors $\mathrm{B}$ and $\mathrm{H}$ complement receptors, and bovine conglutinins. J. Exp. Med. 583:334-352.

33. Davies, E. G., D. Isaacs, and R. J. Levinsky. 1982. Defective immune interferon production and natural killer activity associated with poor neutrophil mobility and delayed umbilical cord separation. Clin. Exp. Immunol. 50:454-460.

34. Van Agthoven, A. J., and A. Truneh. 1985. Lymphocyte function associated antigens one (LFA-1) on B and T lymphocytes bind a monoclonal antibody with different affinities. Cell. Immunol. 91:255-62.

35. Davignon, D., E. Martz, T. Reynolds, K. Kürzinger, and T. A. Springer. 1981. Monoclonal antibody to a novel lymphocyte junction associated antigen (LFA-1). Mechanism of blockade of T lymphocytemediated killing and effects on other $\mathrm{T}$ and $\mathrm{B}$ lymphocyte function. $J$. Immunol. 127:590-595.

36. Biddison, B. W. 1985. Role of cell surface molecules in recognition of SB antigens by human $\mathrm{T}$ cell clones in Human $\mathrm{T}$ cell clones. A new approach to immune regulation. M. Feldmann, editor. Humana Press, London. In press. 